\author{
Драгиша Бојовић \\ Универзитет у Ниму, Филозофски факултет \\ Центар за чрквене студије, Ниш - Србија \\ e-mail: dragisa.bojovic@filfak.ni.ac.rs
}

\title{
САВИН СИЛАЗАК СА ГОРЕ ИЛИ: ДОМЕНТИЈАНОВО СИНАЈСКО ОГЛЕДАЛО
}

Апстракт: У раду се говори о одласку Светога Саве на Синајску Гору, коју је он посетио приликом другог путовања у Свету Земьу. Посебна пажња је посвећена симболици Савиног силаска са Горе, као и идејама истакнутим у Доментијановој похвали Светоме Сави, која има посебну функиију у „Житију Светога Саве“ и у оквиру поменутог описа. Сам опис и похвала разматрају се и у контексту идеје о „новом Израиљу“" која није нова у српској средњовековној књижевности, али код Доментијана добија значајно место. Богородица.

Кључне речи: Свети Сава, Доментијан, Синајска Гора, Мојсије, Пресвета

Свети Сава, први архиепископ српски, у више наврата је посећивао бројна света места, од Свете Горе, преко Палестине, Сирије, Персије и Египта, ишао трагом патријараха, пророка и апостола и поклањао се местима мисије и страдања Господа Исуса Христа. ${ }^{1}$ Све је то забележио умни хиландарски старац Доментијан, ученик Светога Саве, доносећи не само оно што је документарно и хагиографско, већ у свакоме Савином сусрету са светим местима тражећи и налазећи симболику Савиног живота. Иако постоји нескривена тенденција да свог учитеља непрестано пореди са Христом, стиче се утисак да је огледало Савиног живота уздигнуто на Синајској Гори, а читаоцима предочено под Гором. ${ }^{2}$ Опис Савине посете синајским светињама постаје изванредна прилика да се кроз поређење са оним, који се управо на Синају лицем у лице срео са Господом, потврди у континуитету боголикост српског богоносца који не само да је раван великом боговидцу, већ га и умногоме превазилази. Тако Синај, место божанског откривења, постаје, не само за Мојсија, већ и за Светога Саву и место огледања и тријумфа нетварног и невидљивог.

Доментијанов опис Савиног путовања на Синајску Гору има необичну композицију и није строго подређен хронологији и нарацији. Централно место у овој епизоди припада похвали Светоме Сави, коју Доментијан конституише на сталним поређењима српског архиепископа са великим боговидцем Мојсијем. Значајан елемент поређења, који до сада није посебно разматран, јесте пењање на врх Горе, али и силазак са Горе.

Пошто је Савин долазак на Синајску Гору, на њен „свети врх“, истакнут на самом почетку описа, то је и прилика да се подсети на оне догађаје из живота Мојсијевог и

1 О путовањима Светога Саве у Свету Земљу видети: Миљковић 2008; Марковић 2009.

2 Мотив горе присутан је већ у првим српским записима Димитрија Синаита, насталим управо на Синајској Гори. Видети: Савић 2019, 97. 
историје Израиља, у којима Мојсијеви сусрети са Богом заузимају централно место. Када је Сава дошао у Манастир Пречисте Богородице, Доментијан експлицира догађај јављања Господњег из купине која је горела а није сагоревала. Пошто је Мојсију послата порука да изује обућу на светом месту, и Сава на том месту бос служи свету литургију: „И дошавши у Град Синајски би часно примљен од епископа тога града. И дошавши у манастир Пречисте Богородице, поклони се светој цркви и тој самој Добротворци и светоме месту, где купина огњем горећи не изгараше, где сам Господ из купине, која је горела пламеном, рече ка великом пророку Мојсију: 'Изуј обућу са својих ногу јер је место на коме стојиш земља света' (II Мојс. 3,5); тамо и до данас јереји босе служе свету литургију. И овај сам Преосвећени на месту том служио је пред Господом свету литургију на исти начин, по речи Господњој, на земљи светој светолепно послуживши, и прослави Оца и Сина и Светога Духа, и Ону која је пространија од небеса и шира од земље, Пречисту Његову Матер, која је Бога у себе сместила.“3

Пошто је Доментијанова интенција да кључне поруке пошаље након Савиног силаска са Синајске Горе, било је неопходно да нас, пре тога, обавести о Савином изласку на Гору, те да нас подсети на још један разговор Господа и Мојсија: „Горе се попевши, на свети врх Горе Синајске, где Господ Бог Сведржитељ много пута силажаше са славом небесном, дајући закон вазљубљеном Израиљу, горе растапајући и сатирући камење силом својом, и где рече великоме пророку Мојсију: 'Благодат имаш од мене'; а велики боговидац одговори ка Господу Сведржитељу: 'Ако сам благодат нашао пред тобом, јави ми се, да те видим разумно'. А Бог ће к њему: 'Не може човек жив у телу видети лица мојега и жив бити, али ево у мене место свето, и стаћеш при камену, и покрићу те руком мојом, и када прођем са славом мојом, и када подигнем руку моју, и видећеш леђа моја а лице моје неће ти се јавити' (II Мојс. 33, 12,13,18,20-23). А велики Мојсије, веома покорив слуга и добро бојажљив, чувши славу Бога Вишњега, веома уздрхта од славе и крепости Бога Сведржитеља, и помишљаше да бежи, али не имађаше куда, већ у великом страху узмицаше назад, и гора као восак растопивши се од лица Бога Јаковљег, од страха сама чињаше пут њему посред целога камена, а Мојсије веома бежаше дуж камена који се растопио од страха Господњег више него Јордан, када се у њему крштавао Господ.“4 Овде је реч и о подсећању на догађај из Друге књиге Мојсијеве (33, 20-23), где важно место заузима симболика камена. ${ }^{5}$ Том камену, на којем је стајао Мојсије, поклониће се Свети Сава видевши, као и Мојсије раније, самога Господа: „И Преосвећени, узишавши на то место, поклони се, и целова свето подложење свемоћне деснице на светом камену том и на великом боговидцу, и ту многољубазно целовање сатвори, великом жалошћу узмучив се; не хтеде се отргнути од тога камена, као самога тога видећи који је преклонио небеса и сишао, и као да је ту крепка и свесилна света мишица Његова и мислећи да се још није подигла, и умиљење из срца приносећи, умним и срдачним очима и душевнима гледаше Онога који горе седи на престолу херувимском, чекајући од Њега богате милости, видећи га вернога у обећањима, нераскајаног у благодети, који свакоме молбу испуњује.“6

Након овога следи Савин силазак са Горе. У Другој књизи Мојсијевој сваки силазак Мојсијев са Горе у функцији је саопштавања важних порука Израиљу. У првом великом силаску Мојсије саопштава народу, односно „синовима Израиљевим“ да ће они

3 Доментијан 2001, 371.

4 Доментијан 2001, 373.

5 Види и: Пс 118, 22; 2Петар 2, 4: „Кад дођете к њему као камену живу, који је, истина, од људи одбачен, али од Бога изабран и прибран.“

6 Доментијан 2001, 373. 
бити „царство свештеничко и народ свет““ (2Мојс 2, 6-7). ${ }^{7}$ Приликом другог силаска Мојсије преноси поруку Господа о освећењу народа и прању хаљина (2Мојс 19, 10-15). Следећи силазак са Горе извршава се након двоструке заповести коју Господ изриче Мојсију, тражећи да народ не излази на Гору да не би изгинуо (2Мојс 19, 21-25).

Савин силазак са Горе прилика је за Доментијана да, путем похвале, пренесе поруку српском, богоизабраном, народу, „новом Израиљу“, да је српски богоносац (Сава) раван боговидцу Мојсију, а у многим примерима га и превазилази: „И сиђе са Горе свети богоносац, поставши сличан великоме боговидцу, носећи не само самога Бога у себи и на себи, већ и Његовом благодаћу украшен. А овај други боговидац постаде, и удостоји се видети не само леђа Божја, већ се удостоји, благодаћу дарованом Њему с висина, да служи самоме Господу светошћу и истином пред Њим у све дане свога живота. “8

Након тога, Доментијан исписује похвалу Светоме Сави која постаје својеврсно огледало у коме се препознају најзначајнији догађаји из његовог живота и сублимисани најзначајнији елементи житија. Са једне стране, види се ретроспектива дотадашњих Савиних чуда (која су, као у огледалу, слика Мојсијевих чуда), а на другој се наговештава, преко пророчанства Светог Симеона, шта ће се у будућности догодити. Када је реч о чудима, Љиљана Јухас Георгиевска апострофира следећа Мојсијева чуда: претварање кише у град и река у крв, пресушивање извора и њихово испуњавање крвљу, помор египатских првенаца, потапање Фараона у Црвеном мору, добављање воде у Синајској пустињи, победа у бици са Амаличанима, појава препелица, прехрањивање Израиљаца у пустињи маном..$^{9}$ Ова чуда имају паралеле у неким од ових Савиних чуда: чудо са градом, чудо са млеком, чудо са Стрезом, чудо на Сиријском мору када је Сава молитвом укротио огромне морске таласе и заповедио мору да ћути, чудо са рибом, чудо са морским разбојницима, чудо са раслабљеним. ${ }^{10}$

Поред тога што ствара, преко сродних чуда, јединствену паралелу између Мојсија и Светога Саве, похвала је и својеврсно објављење „новог“ или ,другог Израиља“, Светог Саве и српског народа. Сава је „други Израиљ“ (други Јаков), Богом подигнут, који је привео Господу нове људе. ${ }^{11}$ Као што је Мојсије предавао Израиљу све заповести под Гором, тако и Доментијан, након Савиног силаска са Горе, објављује да и Свети Сава деци свога отачаства предаје све од Господа заповеђено: „Онај велики боговидац хиљаде бројем изведе из ропства народ израиљски, а овај Преосвећени безброј правоверних људи сатвори богоразумним својим учењем. И од преваре идолске избавивши их, приведе Господу. Првом Израиљу и деци његовој усињење и слава и обећања, а онима који не остадоше у његовом завету, догоди се жалост. А на овом Преосвећеном богато се утврди милост Божја, усињење и слава и обећање будућих добара бесконачног живота самим Господом њему би дато, и назва се нови Израиљ, и све Господом обећано предаде деци свога отачаства." "12

Међу доминантним мотивима у похвали спада и мотив Свете Горе као еквивалента Синајској Гори. Поред тога, и Пресвета Богородица (као света гора) јесте Савино огледало „неопалиме купине“, коју он прозире богомисаоним очима: „Онај велики боговидаоц пророчким очима виде купину навештену на Синају како огњем гори и не сагорева и гласом Господа Бога из пламена послан би у Египат да изведе Израиљ из

\footnotetext{
7 Види: 2Петар 2, 9.

8 Доментијан 2001, 375.

9 Јухас Георгиевска 2001, LXXVI

10 Јухас Георгиевска 2001, LXXVII

11 Доментијан 2001, 375.

12 Доментијан 2001, 379.
} 
ропства Фараоновог; а овај Преосвећени, самим Господом назнаменан још у утроби матерњој, и из младости анђелски живот почевши, и Духом Светим наоружан, богомисаоним очима прозре, пре постанка небеса и земље и пре свих векова од Оца небесног наречену Божју матер и богогласним пророцима проглашену Свету Гору13, пречисту и сеновиту, истиниту Богородицу, коју предобри Бог изволи као станиште себи, и овом богогласном младићу даде миг да тамо иде. “14 У завршном делу овог цитата крије се сложена семантика Богородице Горе, која има и иконографске паралеле, а која је нарочито изражена у Теодосијевом Житију Светога Саве. ${ }^{15}$ Описујући излазак Светог Саве из Хиландара и одлазак у Солун и манастир Филокал, Теодосије говори о Савином сну у којем је видео, према представи и визији пророка Данила, „гору вишу од небеских гора“, Пресвету Богородицу: „Када је дошла ноћ и када је легао да се одмори, гора мислена и света, гора Божија, гора зелена, гора натопљена Духом, гора небу слична, гора виша од небеских гора, свима анђелским силама подобна, то јест свечиста Дева и Мати Бога мојега, од које се без семена, без људске руке, од њених девичанских спона као од стене велике, по чудесном Данилу, камен Христос отрже и све идоле бесовске сатре, јављањем у сну подиже душу његову од унинија..." ${ }^{16}$ И Доментијан у наведеном цитату говори о Богородици, која је богогласним пророцима проглашена светом гором. Управо је у визији пророка Данила она гора, па у овом контексту Доментијан првенствено апострофира њу, Пресвету Богородицу, па тек онда Свету Гору, перивој Пресвете Богородице, на коју одлази млади Растко. Може се рећи да и Доментијан и Теодосије доносе представу Богородице Горе, али ово Доментијаново место није до сада препознато и овако тумачено, али је несумњиво оно једно од оних места са јасно израженом теотоколошком симболиком и префигурацијом Богородице.

У похвали постоји још једна префигурација Богородице, истакнута цитатом из догматика петог гласа Октоиха, чији је аутор Свети Јован Дамаскин, а чији први стих гласи - „У Црвеном мору некада се приказа слика невесте, која не позна мужа.“ Код Доментијана стоји: „Онај велики боговидац у Црвеном мору написа у старини слику невесте која није искусила брак. “17 Префигурација Богородице је само Црвено море које је „само једном разделило своје воде за прелазак јеврејског народа, а после преласка воде су се саставиле, тако се само једном Бог Израиљев оваплотио и родио од Богородице, која је остала Дева. ${ }^{\text {"18 }}$

Доментијанова похвала још показује да се Свети Сава на Светој Гори напаја са „извора богословља“ који врхуни у „великим Божјим чудесима“. Живот на Светој Гори

13 Управо ова формулација асоцира на префигурацију Богородице као Горе у Књизи пророка Данила: 2, 34. Минијатуре Богородице-Горе и Христа-Камена, као илустрација 68. псалма, који је коментарисан речима пророка Данила, постоје већ у псалтиру Хлудова. Види: Радојчић 1956. Прештампано у Радојчић 1965,120 . У овом контексту треба посматрати и Доментијанову симболику камена, где камен симболише самога Христа. Видети фусноту бр. 6.

14 Доментијан 2001, 377. Српскословенски текст на стр. 376.

15 Радојчић 1956. Као што видимо, похвала крије извесне детаље, који су у Теодосијевом житију развијени у читаве епизоде. Поред епизоде о Богородици Гори, ту је и асоцијација на кисељење млека, које је у Теодосијевом житију описано као посебно чудо. Види: Теодосије 1984, 112.

16 Теодосије 1984, 130.

17 Доментијан 2001, 383.

18 Радовановић 1988, 153. Јанко Радовановић је указао на повезаност догматика петог гласа са једном илустрацијом из српског Минхенског псалтира (лист 227') на коме се налази минијатура са четири сцене, које је управо ликовни еквивалент овог догматика: Прелазак Јевреја преко Црвеног мора, Благовести, Рођење Христово и Купина неопалима. Видети: Радовановић 1988, $151-154$. 
је Савина истинска припрема за сучељење са Синајском Гором, за апостолски рад у отачаству, али и за апостолску мисију: „А он са љубављу примивши глас Господа Бога, и као други Илија Тесвићанин у Свету Гору потече и у њој васпитан би храњен сладошћу анђелском и пребогатим Оцем небеским. Јеванђелском благодаћу изливеном у цео свет украшен би од Христа, љубитеља свога, и ту поцрпе извор богословља великих Божјих чудеса, и отуда отишавши на исток, објави се као сапрестолник апостолски, удостојен преизбилне благодати ових светих боговидаца, и Духом Светим окрилаћен, анђелским крилима као на облак узлете од истока ка западу, и научи доброј вери не само своје отачаство, већ оптече истоке и западе као сунце, и богомисаоним својим учењем небројено мноштво народа од преваре избавивши, са собом Господу приведе.“19 Доментијан има потребу да још једном истакне да Сава у Синајску Гору долази из Свете Горе. Стигавши на њу, он није чуо глас Господа из пламена, попут Мојсија, већ је, превазишавши Мојсија, постао стан самоме Господу примивши га у своје срце и у своју душу: „И Богом израсли изданак од Горе Свете најпосле потече у Гору Синајску. И светоме месту поклонивши се, и Господу послуживши на тој светој земљи, прослави Оца небеснога, и не чу гласа из пламена, већ самога тога даваоца гласа, истинито тело и крв Његову пречисту, изливену за живот света, примивши жар самотрења тајне Божје у пресвету своју душу, и назва се други пророк, као Исаија, који је од серафима жар примио, а овај Преосвећени, сам телесни серафим, постаде стан самоме Господу, имајући у срцу своме и у души својој Онога који почива на светима и који се поје од серафима и слави од херувима.“20 Тиме се испунило пророштво Светога Симеона да ће Савина душа постати престо самоме Господу. ${ }^{21}$ Поред тога, Доментијан предочава у свом синајском огледалу да је Сава примио све Духом Светим, а не на каменим плочама или мастилом написано. Духовним поукама он је испунио закон и просветио своје отачаство. Док Мојсијева чуда доприносе физичком опстанку и преживљавању Израиља у пустињи, Савина чуда, на другој страни, усмерена су ка духовном добитку и духовном напајању: „Онај велики боговидац у пустињи напоји жедни Израиљ, а овај Преосвећени сваком добром вером напоји своје отачаство, које је од почетка жедно било истинитога пића, Христа истинитога Бога нашега. “22 Тако још и физичка победа над непријатељем постаје израз духовних поступака и силе часнога крста. ${ }^{23}$

Иако је похвала грађена на поређењима са Мојсијем, она доноси и кључне христолошке поруке, међу којима је и она да Сава Христом и светим тајнама, које је он установио, превазилази самог Мојсија: „Онај велики боговидац нечисте очисти крвљу јунаца и коза, а овај Преосвећени истинитом крвљу Божјом, изливеном из ребара Господњих и њоме освећиваше оне који прилазе к њему са вером.“24 Сава је, идући за Господом својим, светим крштењем, водом и духом, покајањем и исповедањем, осветио своје отачаство и открио основе васељене заповешћу Оца небеснога. ${ }^{25}$

Читава похвала наговештава надмоћ Савину над Мојсијем, а поједини њени делово експлицитно говоре да је српски архиепископ, попут Јакова у односу на брата Исава, преузео првенство Израиљево и са самим Христом се сјединио: „Онај велики боговидац руком Господњом са речју својом изби првенце египатске, а овај Преосвећени

19 Доментијан 2001, 391.

20 Доментијан 2001, 377.

21 Доментијан 2001, 379.

22 Доментијан 2001, 381.

23 Доментијан 2001, 381.

24 Доментијан 2001, 383.

25 Доментијан 2001, 387. 
узе првенство Израиљево и ка самоме Христу Господу, првенцу из мртвих, пресели се у Вишњи Јерусалим. ${ }^{\text {“26 } И ~ к а д а ~ Д о м е н т и ј а н ~ у ~ п о х в а л и ~ н е ~ а п о с т р о ф и р а ~ с а м о г а ~ Х р и с т а, ~ т р е б а ~}$ имати у виду да поређења са Мојсијем носе христолошки контекст, јер Мојсије изображава самога Христа. И нека његова чуда, која су и у похвали предмет поређења, префигурација су Христа (победа над Амаликом и сила крста). Григорије Палама каже да је Мојсије као претеча Христов „и сам сасвим јасно предизобразио Христа и образ Крста и спасење које од њега долази; усправно поставивши палицу, он је преко ње раширио руке и тако, по слици Крста, представио себе (као разапетог) на палици, потпуно нагнао Амалика у бекство.“27

Као што Мојсије првом Израиљу преноси заповести Божје, тако и Сава своме отачаству оставља завештање. Доментијан жели да део Савиног завештања ${ }^{28}$ саопшти управо након његовог силаска са Горе како би и тиме уподобио свог јунака Мојсију, а српски народ, коме је завештање упућено, уподобио Израиљу представивши га и на тај начин као „нови Израиљ“: „Онај велики боговидац заповеди целом скупу Израиљевом: 'Исперите ризе своје и у три дана будите чисти од ложница ваших, да се удостојите истинитог боговиђења, и бићете достојни да слушате глас Господа Бога вашега' (II Мојс.19,10,11); а овај Преосвећени засведочи сабору свога отачаства, архијерејима, јерејима, преподобним и богоносним монасима и свим сродницима својим и свој деци свога отачаства, говорећи: 'Сведочанство Господње, свето јеванђелско и истинито законоположење и апостолска предања и пророчке проповеди и светих богоносних отаца исправљења и мноме предана вам божанска учења, добро сачувавши испуните, да Господ да̂ вама добру и пуну меру за то у онај велики и просвећени дан, и да чисти будете не само у три дана, већ да будете свети телом и духом и у све дане живота вашега; и 'да су бедра ваша препојасана истином' (Лк.12,35), и да светилници ваши горе милостињом према ништима, и да сте ви слични људима који чекају Господина свога и творе вољу Његову, којима је Господ на небесима спремио свој престол и да Господ Бог ваш, дошавши, нађе вас спремне, и не само да се удостојите да чујете глас Господа Бога вашега, већ и да се настаните са Њим у бесконачне векове, да се реч Господња на вама изврши: 'Јер биће' рече - 'први последњи а последњи први' (Мт. 19,30).“29

Завршници похвале припада, и раније делимично у њој исказаном, пророчанство које је Свети Симеон изрекао о Светоме Сави, а у којем препознајемо утицај Светог Јована Златоуста на Доментијана кроз поређење Светог Саве са Игњатијем Богоносцем ${ }^{30}$ : „Сада се зби пророчанство богоноснога оца нашега Светога Симеона, које по напуштању овога живота унапред објави Светим Духом, љубљеноме своме сину, благодетноме кир Сави: „Дара небеснога удостојиће те љубитељ твој Христос, и на истоку примићеш небесну власт, да везујеш и дрешиш кривице људских грехова, и постаћеш заједничар апостолског седења; истоке и западе проћи ћеш, самим Господом провођен, и као сунце обасјаћеш долине и брда, и градове све оптећи ћеш, као Игњатије Богоносац и испитаћеш све неиспитане путеве Владике свога Господа Сведржитеља, и свима ћеш се часно поклонити, и удостојен Његове благодети, од истока доћи ћеш к мени, и са Господом настанићеш се у бесконачне векове, амин.“"31

26 Доментијан 2001, 381.

27 Григорије Палама 2005, 88. О старозаветном образу крста видети: Бојовић 2006.

28 О Савиним завештањима видети: Бојовић 2019.

29 Доментијан 2001, 389.

30 Бојовић 2019а.

31 Доментијан 2001, 391. 
Тек након завршетка похвале Доментијан нас обавештава да је Сава на Синају провео Васкршњи пост наглашавајући још једном да је Христос онај духовни залог и награда, коју прима Сава на путу од запада ка истоку, те да је смисао његовог доласка на исток задобијање самога Христа, који постаје спаситељ његовог народа: „Провевши ту на Синају свету Четрдесетницу у ћутању, увек стражу држећи у дому душевном, крепким умом бдијући и стражарећи, истинити пастир, на крајевима земље бдијући за стадо свога отачаства, отворено око душевно имајући, ка свевидећем свагда погледајући, и вечна блага прозирући Духом Светим, и радујући се у нади својој, и помишљајући свагда: 'Шта и како и чега ради је ово моје течење од запада ка истинитоме истоку, и шта је добитак мој? Христос сведобри Господ, просвећење мени и моме отачаству, и спаситељ народу моме, који је рекао: 'Тражите и наћи ћете, куцајте и отвориће вам се; јер сваки који моли примиће, који тражи наћи ће, и ономе који куца отвориће се.'“ (Мт. 7,7-8; Лк 11,9-10)32

Одан подвигу ћутања и на Синајској Гори, Светом Сави је увек на уму онај страшни дан када ће сви одговарати пред лицем судије: „И увек чувајући уста своја и језик свој, да ни речју ни делом не отпадне од страшне заповести Господње, и никада се не удостоји речи празне, већ је увек имао страшну реч пред очима душевним, да ће одговарати Страшноме на Страшноме суду Његовом. И у све часове бринуо се да се нађе изван страха и бојазни.“"33 Опис Савиног боравка на Синају Доментијан завршава информацијом да је на крају тог боравка, баш као и на почетку, служио свету литургију у Манастиру Пресвете Богородице: „И ту служивши свету литургију у дому Пресвете Богородице, и преклонивши своја колена, и помоливши се ка Ономе који га је створио, и ка Пречистој Његовој матери, и тако врати се од Свете Горе Синајске.““34

Иако је опис Савиног боравка на Синајској Гори у знаку асоцијација на старозаветне догађаје, јасна је њихова христолошка перспектива, као и препознавање Христових и Богородичиних префигурација. Главне христолошке поруке односе се на Савино уподобљавање Христу, који је пребивао у његовом срцу и његовој души. Поред тога, Сава је испунио Христово јеванђеље, Господу привео савршен народ и просветио га добром вером и светим причешћем.

Савином доласку на Синајску Гору претходи пут, који је исти као и пут којим су Пресвета Богородица, њен заручник Јосиф и младенац Христос избегли пред Иродом у Египат. ${ }^{35}$ Тиме је додатно назначен теотоколошки карактер овог описа. Након Синајске Горе, Свети Сава одлази у Јерусалим и још једном се поклања гробу Господњем. Као да из Богородичиних руку одлази у наручје самога Господа Исуса Христа.

32 Доментијан 2001, 391.

33 Доментијан 2001, 391.

34 Доментијан 2001, 395.

35 Доментијан 2001, 367. 


\section{Извори и литература}

Доментијан (2001). Житије Светог Саве. Београд: Српска књижевна задруга

Григорије Палама, Свети (2005). Господе, просвети таму моју. Сабране беседе, са грчког Антонина Пантелић. Београд: Православна мисионарска школа при Храму Светог Александра Невског

Свето Писмо Старога и Новога Завјета (1995). Београд: Библијско друштво

Теодосије (1984). Житије Светог Саве. Београд: Српска књижевна задруга

$$
* * *
$$

Бојовић, Драгиша (2006). Старозаветни образ крста. Црквене студије 3. Ниш: Центар за црквене студије, 199-209.

Бојовић, Драгиша (2019). Шта је написао Свети Сава. Црквене студије 16/1. Ниш: Центар за црквене студије, 299-310.

Бојовић (2019а). Српска књижевност и Свето Предање. Истраживања рецепиије библијске и светоотачке књижевности. Београд: Завод за уџбенике

Јухас Георгиевска, Љиљана (2001). Кьижевно дело јеромонаха Доментијана. у: Доментијан, Житије Светог Саве, Београд: Српска књижевна задруга

Миљковић, Бојан (2008). Житија Светог Саве као извори за историју средњовековне уметности. Београд: Византолошки институт САНУ

Марковић, Миодраг (2009). Прво путовање Светог Саве у Палестину и његов значај за српску средњовековну уметност. Београд: Византолошки институт САНУ

Радовановић, Јанко (1988). Иконографска истраживања српског сликарства $X I I I$ и XIV века. Београд: Балканолошки институт САНУ

Радојчић, Светозар (1956). Епизода о Богородици-Гори у Теодосијевом ,Животу св. Саве“ и њена веза са сликарством XIII и XIV века. Прилози за књижевност, језик, историју и фолклор 3-4, Београд, 212-222.

Радојчић, Светозар (1965). Текстови и фреске. Нови Сад: Матица српска

Савић, Виктор (2019). Српска књижевна реч у својим првим столећима. Подгорица, Ниш: Матица српска, Друштво чланова у Црној Гори; Међународни центар за православне студије 


\section{Dragiša Bojović}

\section{SAVA'S DESCENT FROM THE MOUNT \\ OR: DOMENTIAN'S SINAI MIRROR}

The paper discusses St. Sava's trip to Mount Sinai, which he visited during his second travel to the Holy Land. Particular attention is paid to the symbolism of Sava's descent from the Mount, and to the ideas pointed out in Domentian's Praise of St. Sava, which has a specific function in both "The Life of St. Sava" and the aforementioned work. The description and praise are also considered as part of the idea of "the new Israel", which was not new in Serbian medieval literature, but would be given the strongest emphasis precisely by Domentian. The final part of the paper stresses the importance of a Theotokological and Christological framework for the description of Sava's stay on Mount Sinai. 